\title{
ANALISIS PENGARUH NPF, BOPO, CAR, FDR DAN NIM TERHADAP \\ RETURN ON ASSET (ROA) PADA BANK UMUM SYARIAH \\ DI INDONESIA TAHUN 2013-2017
}

\author{
Dedi Irawan ${ }^{1)}$, Haryadi ${ }^{2)}$, Enggar Diah Puspa Arum ${ }^{3)}$ \\ 1)(Alumni Magister Ilmu Akuntansi Pascasarjana Universitas Jambi Tahun 2019 \\ ${ }^{2 \& 3)}$ Dosen Pembimbing
}

\begin{abstract}
This research aims to determine the effect of NPF, BOPO, CAR, FDR and NIM on Return On Asset (ROA) of Islamic Comercial Banks for year 2013-2017. Data analysis of this research are using descriptive statistics techniques and testing using classic assumption test, multiple regresssion analysis, hypothesis testing and coefisient of determination. the result of the research shows the simultaneously NPF, BOPO, CAR, FDR dan NIM had effect on return on asset (ROA), partially NPF had no effect on return on asset (ROA), BOPO had effect on return on asset (ROA), CAR had effect on the return on asset (ROA), FDR had no effect on the return on asset (ROA) and NIM had effect on return on asset (ROA).
\end{abstract}

Keywords: Islamic Comercial Banks, Return On Asset (ROA), NPF, BOPO, CAR, FDR, NIM.

\begin{abstract}
ABSTRAK
Penelitian ini bertujuan untuk mengetahui pengaruh NPF, BOPO, CAR, FDR dan NIM terhadap Return On Asset (ROA) Pada Bank Umum Syariah di Indonesia tahun 2013-2017. Analisis data pada penelitian ini menggunakan teknik statistik deskriptif dan pengujiannya menggunakan asumsi klasik, regresi berganda, uji hipotesis dan koefisien determinasi. Hasil penelitian menunjukan bahwa secara simultan NPF, BOPO, CAR, FDR dan NIM berpengaruh terhadap Return On Asset (ROA). Secara parsial NPF tidak berpengaruh terhadap return on asset (ROA), BOPO berpengaruh terhadap return on asset (ROA), CAR berpengaruh terhadap return on asset (ROA), FDR tidak berpengaruh terhadap return on asset (ROA) dan NIM berpengaruh terhadap return on asset (ROA).
\end{abstract}

Kata kunci: Bank Umum Syariah, Return On Asset (ROA). NPF, BOPO, CAR, FDR, NIM. 


\section{PENDAHULUAN}

\subsection{Latar Belakang Penelitian}

Menurut Undang-Undang Nomor 10 tahun 1998, bank adalah suatu badan usaha yang menghimpun dana dari masyarakat dalam bentuk simpanan dan menyalurkannya kepada masyarakat dalam bentuk kredit dalam rangka meningkatkan taraf hidup masyarakat. Adanya fungsi bank tersebut telah menjadikan pertumbuhan suatu bank ditentukan oleh seberapa besar kemampuan bank dalam menghimpun dana simpanan (deposit) dan seberapa besar kemampuannya untuk menyalurkan dana tersebut kepada masyarakat dalam bentuk aktiva produktif, sehingga bank dapat menghasilkan laba yang diharapkan.

Berdasarkan hasil pengumpulan data dari masingmasing Bank Umum Syariah di Indonesia selama 5 tahun, maka dapat diketahui rata-rata rasio pada Bank Umum Syariah di Indonesia dari tahun 2013-2017, Hal ini menunjukkan hasil penelitian yang bervariasi serta terlihat adanya research gap dan disebabkan juga dengan rendahnya rasio ROA pada PT. Bank Syariah Mandiri PT. Bank Syariah Muamalat Indonesia, PT. Bank Syariah BNI, PT. Bank Syariah BRI, PT. Bank Mega Syariah indonesia, PT. Bank Panin Syariah, PT. Bank Syariah Bukopin, PT. Bank Victoria Syariah dan PT. Bank BCA Syariah.

Tingginya rasio BOPO pada PT. Muamalat Indonesia, PT. Bank Syariah BRI dan PT. Bank Syariah Bukopin. Rendahnya rasio CAR pada PT. Bank Syariah Bukopin. Rendahnya rasio NIM pada PT. Bank Syariah Muamalat Indonesia, PT. Bank Panin Syariah, PT. Bank Syariah Bukopin, PT. Bank Victoria Syariah, PT. Bank BCA Syariah, oleh karena itu penulis tertarik untuk melakukan penelitian dengan mengkombinasikan rasio-rasio keuangan dari peneliti terdahulu namun dengan populasi dan sampel yang berbeda, dengan judul Analisis Pengaruh NPF, BOPO, CAR, FDR dan NIM Terhadap Return On Asset (ROA) pada Bank Umum Syariah di Indonesia tahun 2013-2017.

\subsection{Rumusan Masalah}

Menurut Undang-Undang Nomor 10 Tahun 1998 bank syariah adalah bank yang melaksanakan kegiatan usahanya berdasarkan prinsip syariah yang dalam kegiatannya memberikan jasa dalam lalu lintas pembayaran. Perkembangan perbankan syariah yang semakin meningkat setiap tahunnya membuat perbankan syariah harus memiliki tingkat kinerja bank yang baik agar dapat bersaing dengan bank konvensional (Rivai, 2007:109). Bank yang tingkat kesehatan dan kestabilannya terjaga dengan baik dari tahun ke tahun pasti akan menarik dan menambah tingkat kepercayaan bagi nasabah maupun investor, sedangkan bila tingkat kesehatan bank dinyatakan kurang sehat, maka hal ini akan membahayakan diri perbankan tersebut serta berbagai pihak terkait (Rivai, 2007). Pada penelitian ini ada beberapa permasalahan yang terjadi pada Bank Umum Syariah diantaranya :
Rendahnya rasio ROA pada PT. Bank Syariah Mandiri sebesar 0,69 \%, PT. Bank Syariah Muamalat Indonesia sebesar 0,24 \%, PT. Bank Syariah BNI sebesar 1,36 \%, PT. Bank Syariah BRI sebesar 0,69 \%, PT. Bank Mega Syariah indonesia sebesar 1,42\%, PT. Bank Panin Syariah sebesar 1,25 \%, PT. Bank Syariah Bukopin sebesar 0,58 \%, PT. Bank Victoria Syariah sebesar 1,26 \% dan PT. Bank BCA Syariah sebesar $1,31 \%$. Berdasarkan aturan yang termuat pada peraturan Bank Indonesia (BI) Nomor 6/9/PBI/2004 tentang tindak lanjut pengawasan dan penetapan status Bank bahwa rasio ROA yang bagus adalah diatas $1,5 \%$. Semakin tinggi rasio ini menunjukan bahwa bank memiliki kemampuan yang besar dalam meningkatkan laba operasi dan prospek masa depannya (Pandia, 2012).

Tingginya rasio BOPO pada PT. Muamalat Indonesia sebesar 96,80 \%, PT. Bank Syariah BRI sebesar 94,11 \% dan PT. Bank Syariah Bukopin sebesar 93,97 \%. Berdasarkan aturan yang termuat pada peraturan Bank Indonesia (BI) Nomor 10/15/PBI/2008 tentang kewajiban modal minimum Bank Umum syariah bahwa rasio BOPO baik apabila dibawah 93\%. Semakin besar rasio ini maka akan semakin kecil atau menurun kinerja keuangan perbankan (Dendawijaya, 2009).

Rendahnya rasio Capital Adequacy Ratio (CAR) pada PT. Bank Syariah Bukopin sebesar 4,10 \%. Berdasarkan aturan yang termuat pada Surat Edaran Bank Indonesia Nomor 23/67/Kep/DIR Tanggal 28 Februari 1991 yang dipertegas melalui peraturan Bank Indonesia (BI) Nomor 31/21/PBI/2004 tentang kewajiban modal minimum Bank, menetapkan bahwa rasio CAR harus mencapai $8 \%$. Semakin tinggi rasio ini semakin baik kondisi suatu Bank (Pandia, 2012).

Tingginya rata-rata rasio Financing to Deposit Ratio (FDR) pada PT. Bank Syariah Mega Indonesia yaitu sebesar 94,35\%. Berdasarkan aturan yang termuat pada peraturan Bank Indonesia (BI) Nomor 18/14/PBI/2016 tentang perubahan keempat atas peraturan Bank Indonesia (BI) Nomor 15/15/PBI/2013 tentang giro wajib minimum Bank Umum dalam rupiah dan valuta asing bagi bank umum konvensional dan syariah bahwa target LDR atau FDR adalah sebesar $80 \%$ sampai dengan $92 \%$. Semakin tinggi rasio FDR maka semakin tinggi dana yang disalurkan ke dana pihak ketiga (DPK). Semakin banyak dana terkumpul, semakin banyak juga pembiayaan yang dapat disalurkan (Rivai, 2007). Dengan penyaluran dana pihak ketiga yang besar maka pendapatan bank akan semakin meningkat, sehingga laba yang diperoleh oleh bank akan besar (Rivai, 2007).

Rendahnya rasio Net Interest Margin (NIM) pada PT. Bank Syariah Muamalat Indonesia sebesar 3,56 \%, PT. Bank Panin Syariah sebesar 4,91 \%, PT. Bank Syariah Bukopin sebesar 3,10 \%, PT. Bank Victoria Syariah sebesar 4,57 \%, PT. BCA Syariah sebesar 4,64 \%. Berdasarkan aturan yang termuat pada peraturan Bank Indonesia (BI) Nomor 10/15/PBI/2008 
tentang kewajiban modal minimum bank umum bahwa batas rasio NIM adalah diatas $6 \%$. Semakin besar rasio ini akan meningkatkan pendapatan bunga atau aktiva produktif yang dikelola bank sehingga kemungkinan suatu bank dalam kondisi bermasalah semakin kecil (Pandia, 2012).

Sehubungan dengan uraian diatas maka rumusan masalah pada penelitian ini adalah sebagai berikut :

1. Apakah NPF, BOPO, CAR, FDR dan NIM secara simultan berpengaruh terhadap Return On Asset (ROA)?

2. Apakah NPF berpengaruh terhadap Return On Asset (ROA)?

3. Apakah BOPO berpengaruh terhadap Return On Asset (ROA)?

4. Apakah CAR berpengaruh terhadap Return On Asset (ROA)?

5. Apakah FDR berpengaruh terhadap Return On Asset (ROA)?

6. Apakah NIM berpengaruh terhadap Return On Asset (ROA)?

\subsection{Tujuan Penelitian}

Tujuan dari penelitian ini adalah:

1. Menganalisis pengaruh NPF, BOPO, CAR, FDR dan NIM secara simultan terhadap Return On Asset (ROA).

2. Menganalisis pengaruh NPF terhadap Return On Asset (ROA).

3. Menganalisis pengaruh BOPO terhadap Return On Asset (ROA).

4. Menganalisis pengaruh CAR terhadap Return On Asset (ROA).

5. Menganalisis pengaruh FDR terhadap Return On Asset (ROA)

6. Menganalisis pengaruh NIM terhadap Return On Asset (ROA).

\subsection{Manfaat Penelitian}

Pada penulisan penelitian tesis ini, diharapkan dapat memberikan kontribusi posisitif terhadap perbankan syariah di Indonesia, yaitu:

1. Para praktisi

Dengan adanya penelitian ini maka akan menjadi suatu bahan masukan informasi dalam merumuskan dan mempertimbangkan kebijakan-kebijakan yang akan dibuat guna meningkatkan kinerja perbankan syariah khususnya Bank Umum Syariah di indonesia.

2. Para akademisi

Dengan adanya penelitian ini maka dapat memberikan kontribusi pemikiran bagi para peneliti dan akan menjadi suatu acuan, referensi, tambahan literatur serta akan menjadi suatu pertimbangan bagi peneliti selanjutnya.

\section{KAJIAN PUSTAKA, PEMIKIRAN, DAN HIPOTESIS}

\section{KERANGKA}

\subsection{Kajian Pustaka}

\subsubsection{Signaling Theory (Teori Sinyal)}

Di dalam teori ini dikemukakan bahwa pihak eksekutif perusahaan akan memiliki informasi yang lebih baik dan cenderung untuk memberikan informasi tersebut kepada calon investor (Ross, 1977).

Pada signalling theory ini terdapat informasi yaitu berupa berita yang bagus yang dimiliki perusahaan yang berkaitan dengan prospek perusahaan dimasa yang akan datang dan diharapkan dapat meningkatkan harga saham perusahaan. Dalam hal ini sinyal dapat juga berupa promosi atau informasi lain yang terkait perusahaan tersebut lebih baik daripada perusahaan lain (Sari dan Zuhrotun, 2006:4).

\subsubsection{Bank}

Bank yaitu suatu lembaga keuangan yang usaha pokoknya menghimpun dana dan menyalurkan kembali dana tersebut ke masyarakat dalam bentuk kredit serta sebagai suatu lembaga yang berfungsi memperlancar aliran lalu lintas pembayaran (Kuncoro, 2002)

Bank syariah yaitu suatu lembaga keuangan yang fungsinya sebagai perantara bagi pihak yang kelebihan dana dengan pihak yang kekurangan dana untuk kegiatan usaha dan kegiatan lainnya sesuai dengan hukum Islam (Suwiknyo, 2010).

\subsubsection{Return On Asset (ROA)}

ROA yaitu suatu rasio yang digunakan untuk mengetahui kemampuan bank dalam menghasilkan keuntungan dari pengelolaan aset yang dimiliki oleh bank (Umam, 2013:257). Berdasarkan aturan yang termuat pada peraturan Bank Indonesia (BI) nomor 6/9/PBI/2004 bahwa rasio ROA yang baik bagi bank adalah diatas $1,5 \%$

\subsubsection{Laporan Keuangan}

Laporan keuangan yaitu suatu struktur yang menyajikan posisi keuangan dan kinerja keuangan dalam sebuah entitas (IAI, 2012). Adapun tujuan utama laporan keuangan ialah sebagai penyajian informasi mengenai posisi keuangan, kinerja keuangan dan arus kas (cash flow) yang berguna bagi para penggunanya (Fahmi, 2012).

\subsubsection{Rasio Keuangan}

Rasio keuangan yaitu suatu angka yang diperoleh dari hasil perbandingan dari satu pos laporan keuangan dengan pos lainnya yang mempunyai hubungan yang relevan dan signifikan (Harahap, 2009). 


\subsubsection{Non Performing Financing (NPF)}

NPF ialah suatu tingkat pengembalian pembiayaan yang diberikan deposan kepada bank dengan kata lain rasio (Ismail, 2011). Berdasarkan aturan yang termuat pada ketetapan Bank Indonesia (BI) nomor 17/11/PBI/2015 bahwa tingkat rasio NPL atau NPF yang sehat pada suatu bank adalah dibawah $5 \%$.

\subsubsection{BOPO}

BOPO adalah suatu rasio perbandingan antara biaya operasional dengan pendapatan operasional (Dendawijaya, 2009). Semakin besar rasio ini maka akan semakin menurun kinerja keuangan suatu bank. Berdasarkan aturan yang termuat pada ketetapan Bank Indonesia (BI) nomor 10/15/PBI/2008 bahwa rasio BOPO yang pada suatu dianggap sehat apabila dibawah $93 \%$.

\subsubsection{Capital Adequacy Ratio (CAR)}

CAR yaitu suatu perbankan mampu membiayai aktivitas kegiatannya dengan kepemilikan modal yang dimilikinya (Fahmi, 2014). Berdasarkan aturan yang termuat dalam surat edaran Bank Indonesia Nomor 23/67/Kep/DIR 28 februari 1991 yang juga dipertegas melalui ketetapan Bank Indonesia (BI) nomor 31/21/PBI/2001 bahwa rasio CAR yang sehat pada suatu bank apabila mencapai $8 \%$.

\subsubsection{Financing to Deposit Ratio (FDR)}

FDR merupakan suatu rasio yang digunakan untuk mengukur likuiditas suatu bank untuk membayar kembali penarikan dana yang dilakukan deposan dengan mengandalkan pembiayaan yang diberikan sebagai sumber likuiditasnya, yaitu dengan cara membagi jumlah pembiayaan yang diberikan oleh bank terhadap dana pihak ketiga (Rivai, 2007:718). Berdasarkan aturan yang termuat dalam ketetapan Bank Indonesia (BI) Nomor 18/14/PBI/2016 tentang perubahan keempat atas peraturan Bank Indonesia (BI) nomor 15/15/PBI/2013 mengenai giro wajib minimum bank umum dalam rupiah dan valuta asing bagi bank umum konvensional dan syariah bahwa tingkat rasio LDR atau FDR yang sehat pada suatu bank apabila $80 \%$ sampai dengan $92 \%$.

\subsubsection{Net Interest Margin (NIM)}

Net Interest Margin (NIM) yaitu suatu rasio yang menunjukkan kemampuan manajemen dalam mengelola aktiva produktifnya untuk menghasilkan pendapatan bunga bersih. Pendapatan bunga bersih diperoleh dari pendapatan bunga dikurangi beban bunga (Almilia dan Herdiningtyas, 2005). Berdasarkan aturan yang termuat pada ketetapan Bank Indonesia (BI) nomor 10/15/PBI/2008 bahwa rasio NIM yang sehat bagi suatu bank apabila diatas $6 \%$.

\subsection{Penelitian Terdahulu}

Tabel 1.

Penelitian Terdahulu

\begin{tabular}{|c|c|c|}
\hline $\begin{array}{l}\text { Nama } \\
\text { Peneliti dan } \\
\text { Sumber }\end{array}$ & Judul & Hasil \\
\hline $\begin{array}{l}\text { Raharjo. } \\
\text { Vol. 15, No. } \\
\text { 2. 2014.. }\end{array}$ & $\begin{array}{lr}\text { Pengaruh rasio } \\
\text { CAR, NPL, LDR, } \\
\text { BOPO, dan NIM } \\
\text { terhadap Kinerja } \\
\text { Bank Umum di } \\
\text { Indonesia. }\end{array}$ & $\begin{array}{l}\text { CAR, NPL, LDR, } \\
\text { BOPO, dan NIM } \\
\text { berpengaruh terhadap } \\
\text { variabel ROA. CAR } \\
\text { berpengaruh negative } \\
\text { dan signifikan terhadap } \\
\text { ROA. NPL dan LDR } \\
\text { berpengaruh negative } \\
\text { terhadap ROA. NIM } \\
\text { berpengaruh positif dan } \\
\text { signifikan terhadap } \\
\text { ROA. }\end{array}$ \\
\hline $\begin{array}{l}\text { Dewi, L. } \\
\text { Eprima. } \\
\text { E,Journal. } \\
\text { Volume } 3 \text { No. } \\
1 \text { tahun } 2015 .\end{array}$ & $\begin{array}{l}\text { Analisis } r \text { NIM, } \\
\text { BOPO, LDR, dan } \\
\text { NPL terhadap ROA } \\
\text { Bank } \quad \text { Umum } \\
\text { Swasta2009-2013). }\end{array}$ & $\begin{array}{l}\text { NIM, BOPO, NPL, dan } \\
\text { LDR berpengaruh } \\
\text { terhadap profitabilitas } \\
\text { baik secara parsial } \\
\text { maupun secara simultan }\end{array}$ \\
\hline $\begin{array}{ll}\text { Volume } & 1, \\
\text { Nomor } & 1 . \\
2015 . & \end{array}$ & $\begin{array}{l}\text { pengaruh } \\
\text { pembiayaan dan } \\
\text { efisiensi terhadap } \\
\text { Profitabilitas Bank } \\
\text { Umum Syariah. }\end{array}$ & $\begin{array}{l}\text { Pembiayaan } \\
\text { berpengaruh } \\
\text { Profitabilitas. } \\
\text { terhadap }\end{array}$ \\
\hline \begin{tabular}{lr}
\multicolumn{2}{r}{ Vol. 33 No. } \\
1 & April \\
2016. &
\end{tabular} & $\begin{array}{lr}\text { Pengaruh } & \text { Rasio } \\
\text { CAR, BOPO, } & \text { LDR, } \\
\text { NIM dan } & \text { NPL } \\
\text { terhadap } & \text { ROA } \\
\text { (Studi Pada } & \text { Bank } \\
\text { Umum } & \text { Yang } \\
\text { Terdaftar di } & \text { Bursa } \\
\text { Efek Indonesia } \\
\text { Periode } & \text { 2012-2014) }\end{array}$ & $\begin{array}{lr}\text { CAR, BOPO, } & \text { LDR, } \\
\text { NIM dan } & \text { NPL secara } \\
\text { simultan } & \text { berpengaruh } \\
\text { signifikan } & \text { terhadap } \\
\text { ROA. } & \\
\text { CAR dan } & \text { NPL tidak } \\
\text { berpengaruh } & \text { secara } \\
\text { signifikan } & \text { terhadap } \\
\text { ROA. BOPO, LDR dan } \\
\text { NIM r berpengaruh } \\
\text { signifikan } & \text { terhadap } \\
\text { ROA. } & \end{array}$ \\
\hline $\begin{array}{l}\text { ISSN: } 2302- \\
8556 \text { Vol.15. } \\
2016 .\end{array}$ & $\begin{array}{l}\text { Analisis } \\
\text { perbandingan } \\
\text { kinerja keuangan } \\
\text { Bank Konvensional } \\
\text { dan Bank Syariah } \\
\text { Periode 2010-2014 }\end{array}$ & $\begin{array}{lr}\text { CAR dan } & \text { NIM } \\
\text { berpengaruh } & \text { positif } \\
\text { terhadap ROA. } & \text { NPL } \\
\text { berpengaruh } & \text { negatif } \\
\text { terhadap ROA. } & \text { NPL } \\
\text { berpengaruh negatif } \\
\text { terhadap ROA. NIM } \\
\text { tidak berpengaruh } \\
\text { terhadap ROA. }\end{array}$ \\
\hline $\begin{array}{l}\text { Vol. 6, No. } 2 . \\
2016 .\end{array}$ & $\begin{array}{l}\text { Analisis Pengaruh } \\
\text { INFLASI, CAR, } \\
\text { FDR, BOPO, dan } \\
\text { NPF Terhadap } \\
\text { Profitabilitas } \\
\text { Perbankan Syariah. }\end{array}$ & $\begin{array}{l}\text { Secara simultan } \\
\text { INFLASI, CAR, FDR, } \\
\text { BOPO, dan NPF } \\
\text { berpengaruh signifikan } \\
\text { terhadap ROA. } \\
\text { Secara parsial, BOPO, } \\
\text { NPF dan CAR pengaruh } \\
\text { negatif signifikan } \\
\text { terhadap ROA. }\end{array}$ \\
\hline
\end{tabular}




\begin{tabular}{|c|c|c|}
\hline $\begin{array}{l}\begin{array}{l}\text { Hijriyani, Z. } \\
\text { Nuri dan } \\
\text { Setiawan. }\end{array} \\
\text { Vol 1.2017. }\end{array}$ & $\begin{array}{l}\text { Analisis } \\
\text { Profitabilitas Bank } \\
\text { Syariah di Indonesia } \\
\text { Sebagai dampak dari } \\
\text { Efisiensi } \\
\text { Operasional }\end{array}$ & $\begin{array}{l}\text { BOPO berpengaruh } \\
\text { negatif terhadap ROA. } \\
\text { FDR tidak berpengaruh } \\
\text { terhadap ROA. }\end{array}$ \\
\hline $\begin{array}{l}\text { Salman, A. } \\
\text { Parisi. } \\
\text { Vol. 2, No } 1 \\
\text { 2017. ISSN: } \\
\text { 2527-3434. }\end{array}$ & 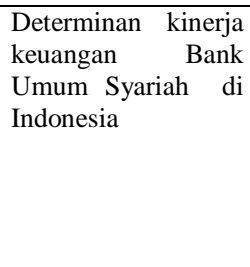 & $\begin{array}{l}\text { CAR, NPF dan NOM } \\
\text { berpengaruh signifikan } \\
\text { positif terhadap ROA. } \\
\begin{array}{l}\text { FDR, dan BOPO } \\
\text { berpengaruh signifikan } \\
\text { negatif terhadap ROA. }\end{array}\end{array}$ \\
\hline & & $\begin{array}{lr}\text { CAR, NPF, } & \text { FDR, } \\
\text { BOPO, dan } & \text { NOM } \\
\text { berpengaruh } & \text { secara } \\
\text { simultan terhadap } & \text { ROA. }\end{array}$ \\
\hline $\begin{array}{l}\text { Sutrisno. } \\
\\
\text { Vol. 11, No.2. } \\
2017 .\end{array}$ & $\begin{array}{l}\text { Risiko dan Kinerja } \\
\text { Bank Perkreditan } \\
\text { Rakyat } \\
\text { (Studi Perbandingan } \\
\text { antara BPR Syariah } \\
\text { dengan } \\
\text { Konvensional di } \\
\text { Indonesia). }\end{array}$ & 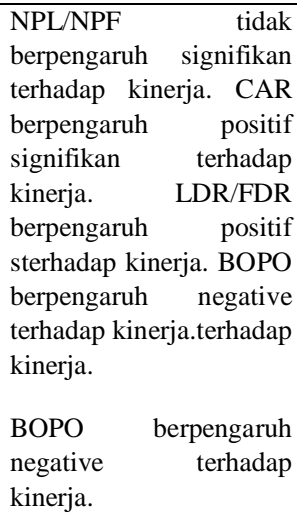 \\
\hline $\begin{array}{l}\text { Hafidz dan } \\
\text { Safira. }\end{array}$ & $\begin{array}{l}\text { Analisis Pengaruh } \\
\text { Manajemen Risiko } \\
\text { Terhadap } \\
\text { 2015). }\end{array}$ & $\begin{array}{lrr}\text { CAR } & \text { Bank } & \text { Umum } \\
\text { Konvensional r } & \\
\text { berpengaruh } & \text { terhadap } \\
\text { ROA.. } & \text { NPL pada } & \text { Bank } \\
\text { Umum } & \text { Konvensional } \\
\text { maupun } & \text { Syariah } & \text { secara } \\
\text { parsial } & \text { berpengaruh } \\
\text { terhadap } & \text { ROA. } & \text { LDR } \\
\text { Bank } & & \text { Umum } \\
\text { Konvensional } & \text { secara } \\
\text { simultan } & \text { berpengaruh } \\
\text { dan secara } & \text { parsial tidak } \\
\text { berpengaruh } & \text { terhadap } \\
\text { ROA. } & \text { LDR } & \text { Bank } \\
\text { Syariah } & \text { berpengaruh } \\
\text { secara simultan } & \text { maupun } \\
\text { parsial ral } & \end{array}$ \\
\hline $\begin{array}{l}2018 . \\
\text { ISSN.2355- } \\
5408 .\end{array}$ & $\begin{array}{lr}\text { Analisis } & \text { Pengaruh } \\
\text { LDR, NPL, NIM } \\
\text { dan CAR } & \text { terhadap } \\
\text { ROA } & \text { Pada } \\
\text { Perbankan } & \text { yang } \\
\text { Terdaftar di } & \text { Bursa } \\
\text { Efek Indonesia } \\
\text { (BEI) Periode 2012- } \\
2016 .\end{array}$ & $\begin{array}{l}\text { Secara simultan : } \\
\text { LDR, NPL, NIM dan } \\
\text { CAR berpengaruh } \\
\text { signifikan terhadap } \\
\text { ROA. } \\
\text { Secara Parsial : } \\
\text { LDR tidak berpengaruh } \\
\text { signifikan terhadap } \\
\text { ROA. NPL dan CAR } \\
\text { berpengaruh negatif dan } \\
\text { signifikan terhadap } \\
\text { ROA. NIM berpengaruh } \\
\text { positif dan signifikan } \\
\text { terhadap ROA. }\end{array}$ \\
\hline
\end{tabular}

\begin{tabular}{|c|c|c|}
\hline $\begin{array}{l}\text { Fatah dan } \\
\text { Rahadian . } \\
\text { Vol.5, No.1 } \\
\text { Maret } 2018 \text {. } \\
\text { ISSN : 2355- } \\
\text { 9357. }\end{array}$ & $\begin{array}{lr}\text { Pengaruh } & \text { CAR, } \\
\text { NPF, } & \text { FDR dan } \\
\text { BOPO } & \text { terhadap } \\
\text { ROA } & \text { Perbankan } \\
\text { Syariah } & \end{array}$ & 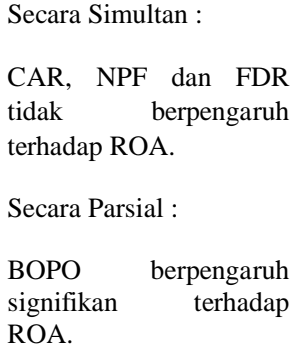 \\
\hline
\end{tabular}

Sumber : Dari Berbagai Sumber.

\subsection{Kerangka Pemikiran}

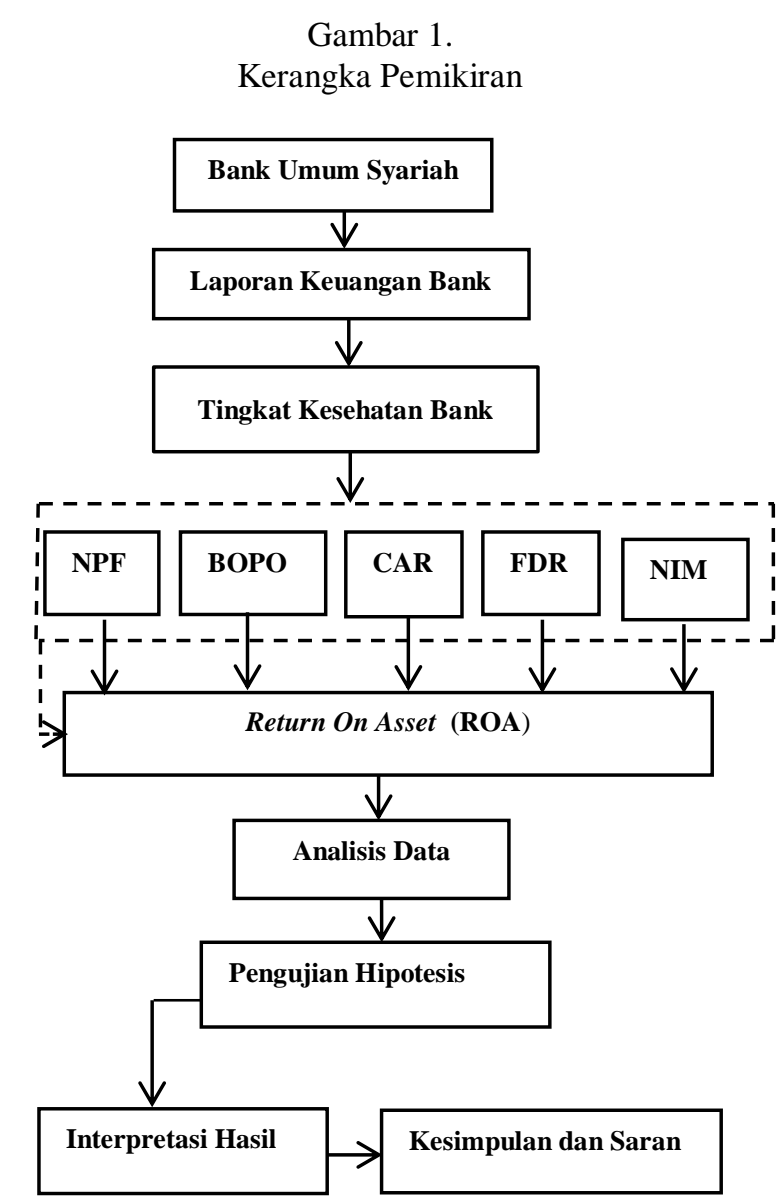

\subsection{Hipotesis Penelitian}

Adapun hipotesis yang diajukan dalam penelitian ini adalah:

$H_{1}$ : NPF, BOPO, CAR, FDR dan NIM secara simultan berpengaruh terhadap Return On Asset (ROA).

$\mathrm{H}_{2}$ : NPF berpengaruh terhadap Return On Asset (ROA).

$\mathrm{H}_{3}$ : BOPO berpengaruh terhadap Return On Asset (ROA).

$H_{4}$ : CAR berpengaruh terhadap Return On Asset (ROA).

$H_{5}$ : FDR berpengaruh terhadap Return On Asset (ROA). 
$H_{6}$ : NIM berpengaruh terhadap Return On Asset (ROA).

\section{METODOLOGI}

\subsection{Objek Penelitian dan Subjek Penelitian}

Populasi yaitu suatu wilayah generalisasi yang terdiri atas objek atau subjek yang mempunyai kualitas dan karakteristik. Sampel merupakan suatu bagian dari jumlah dan karakteristik yang dimiliki oleh populasi tersebut. Teknik pengambilan sampel yang digunakan pada penelitian ini menggunakan teknik sampling jenuh. Sampling jenuh adalah suatu teknik penentuan sampel bila semua anggota populasi dijadikan sampel (Sugiyono, 2016).

Tabel 2.

Populasi dan Sampel Bank Umum Syariah

Tahun 2013-2017

\begin{tabular}{|c|l|}
\hline No. & \multicolumn{1}{|c|}{ Nama Bank } \\
\hline 1 & PT. Bank Syariah Mandiri \\
\hline 2 & PT. Bank Syariah Muamalat Indonesia \\
\hline 3 & PT. Bank Syariah BNI \\
\hline 4 & PT. Bank Syariah BRI \\
\hline 5 & PT. Bank Syariah Mega Indonesia \\
\hline 6 & PT. Bank Jabar dan Banten \\
\hline 7 & PT. Bank Panin Syariah \\
\hline 8 & PT. Bank Syariah Bukopin \\
\hline 9 & PT. Bank Victoria Syariah \\
\hline 10 & PT. BCA Syariah \\
\hline 11 & PT. Maybank Indonesia Syariah \\
\hline
\end{tabular}

Sumber: Bank Indonesia

Pada penelitian ini, peneliti mengunakan pendekatan deskriptif kuantitatif. Deskriptif kuantitatif merupakan suatu jenis penelitian yang bertujuan menjelaskan fenomena yang ada dengan menggunakan angka-angka untuk menjelaskan karakteristik individu maupun suatu kelompok (Narbuko dan Achmadi, 2003).

\subsection{Desain Penelitian}

Pada penelitian ini, peneliti desain yang digunakan adalah kausal komparatif yang bersifat ex post facto (latin = setelah fakta). Kausal komparatif merupakan suatu data yang dikumpulkan setelah semua kejadian yang telah terjadi atau lewat dan mengambil satu atau lebih akibat dan mengujinya dengan menelusur ke masa lalu untuk mencari hubungan sebab-akibat (Narbuko dan Achmadi, 2003).

Penelitian ex post facto dilakukan jika peneliti ingin mengetahui dampak variabel bebas kepada variabel terikat, tetapi data tentang variabel bebas dan terikat sudah tersedia (Samsudi, 2009).

\subsection{Operasionalisasi Variabel}

Tabel 3.

Operasionalisasi Variabel

\begin{tabular}{|l|l|l|l|}
\hline \multirow{2}{*}{ VRB } & \multicolumn{3}{|c|}{ Pengukuran } \\
\cline { 2 - 4 } & \multicolumn{2}{|c|}{ Indikator } & Skala \\
\hline ROA & $\begin{array}{l}\text { Laba sebelum pajak } \\
\text { Rata-rata total asset }\end{array}$ & $100 \%$ & Rasio \\
\hline NPF & $\frac{\text { Pembiayaan }}{\text { Total Pembiayaan }}$ & $100 \%$ & Rasio \\
\hline BOPO & $\begin{array}{l}\text { Biaya Operasional } \\
\text { Pendapatan Operasional }\end{array}$ & $100 \%$ & Rasio \\
\hline CAR & $\begin{array}{l}\text { Modal } \\
\text { ATMR }\end{array}$ & $100 \%$ & Rasio \\
\hline FDR & $\begin{array}{l}\text { Total Pembiayaan } \\
\text { Total dana pihak ketiga }\end{array}$ & $100 \%$ & Rasio \\
\hline NIM & $\begin{array}{l}\text { Pendapatan Bunga B } \\
\text { Rata-rata aktiva produktif }\end{array}$ & $100 \%$ & Rasio \\
\hline
\end{tabular}

Sumber : Dari berbagai sumber

\subsection{Sumber Data}

Pada penelitian ini sumber data yang digunakan adalah data skunder. Data skunder merupakan suatu data yang ada kaitannya dengan masalah yang akan diteliti, yang mana data ini akan mendukung suatu penelitian (Indriantoro dan Supomo, 2002).

\subsection{Teknik Analisis Data}

Pada penelitian ini persamaan regresi linear bergandanya adalah sebagai berikut:

$Y=\alpha+\beta_{1} X_{1}+\beta_{2} X_{2}+\beta_{3} X_{3}+\beta_{4} X_{4}+\beta_{5} X_{5}+e$

\section{HASIL DAN PEMBAHASAN}

\subsection{Hasil Penelitian}

4.1.1. Statistik Deskriptif

Tabel 4.

Hasil Statistik Deskriptif

\begin{tabular}{|l|r|r|r|r|r|}
\hline \multicolumn{7}{|c|}{ Descriptive Statistics } \\
\hline & $\mathrm{N}$ & \multicolumn{1}{c|}{ Min } & \multicolumn{1}{c|}{ Max } & \multicolumn{1}{c|}{ Mean } & $\begin{array}{c}\text { Std. } \\
\text { Deviation }\end{array}$ \\
\hline \multicolumn{1}{|c|}{$\mathrm{Y}$} & 55 &, 02 & 5,50 & 1,2991 & 1,01846 \\
\hline $\mathrm{X}_{1}$ & 55 &, 10 & 4,93 & 2,6485 & 1,57577 \\
\hline $\mathrm{X}_{2}$ & 55 & 67,79 & 99,77 & 88,5469 & 8,26838 \\
\hline $\mathrm{X}_{3}$ & 55 & 2,44 & 75,83 & 20,3742 & 13,66240 \\
\hline $\mathrm{X}_{4}$ & 55 & 71,87 & 110,54 & 89,8765 & 7,37942 \\
\hline $\mathrm{X}_{5}$ & 55 & 2,44 & 10,66 & 5,8051 & 1,89386 \\
\hline Valid N & 55 & & & & \\
(listwise) & 55 & & &
\end{tabular}

Sumber: Pengolahan data dengan SPSS 24.

Berdasarkan hasil uji statistik deskriptif (Tabel 4) di atas, dari 55 sampel data yang diteliti maka dapat diuraikan sebagai berikut: 
1). Nilai minimum pada rasio ROA sebesar 0,02 terdapat pada PT. Bank Bukopin Syariah yang artinya bahwa PT. Bank Bukopin Syariah tidak cukup baik dalam menghasilkan ROA karena jauh dibawah nilai rata-rata keseluruhan bank, nilai maximum pada rasio ROA sebesar 5,50 terdapat pada PT. Maybank Indonesia Syariah yang artinya bahwa PT. Maybank Indonesia Syariah sangat baik dalam membukukan ROA yang melebihi nilai ratarata keseluruhan bank, serta nilai mean sebesar 1,2991. Simpangan baku sebesar 1,01846.

2). Nilai minimum pada rasio NPF sebesar 0,01 terdapat pada PT. BCA Syariah yang artinya bahwa PT. BCA Syariah sangat baik dalam mengelola rasio NPF, nilai maximum rasio NPF sebesar 4,93 pada PT. Maybank Indonesia Syariah yang artinya bahwa PT. Maybank Indonesia Syariah tidak cukup baik dalam mengelola rasio NPF karena melibihi standar yang ditetapkan, serta nilai mean pada rasio NPF sebesar 2,6485. Simpangan baku yang sebesar 1,57577 .

3). Nilai minimum pada rasio BOPO sebesar 67,79 terdapat pada PT. Maybank Indonesia Syariah yang artinya bahwa PT. Maybank Indonesia Syariah sangat baik dalam mengelola rasio BOPO, nilai maximum pada rasio BOPO sebesar 99,77 terdapat pada PT. Bank Syariah BRI yang artinya bahwa PT. Bank Syariah BRI kurang baik dalam mengelola rasio BOPO karena melibihi standar yang ditetapkan, serta nilai mean pada rasio BOPO sebesar 88,5469. Simpangan baku sebesar 8,26838.

4). Nilai minimum pada rasio CAR sebesar 2,44 terdapat pada PT. Bank Syariah Bukopin yang artinya bahwa PT. Bank Syariah Bukopin cukup baik dalam mengelola rasio CAR, nilai maximum pada rasio CAR sebesar 75,83 terdapat pada PT. Maybank Indonesia Syariah yang artinya bahwa PT. Maybank Indonesia Syariah sangat baik dalam mengelola rasio CAR, serta nilai mean pada rasio CAR sebesar 20,3742. Simpangan baku sebesar 13,66240 .

5). Nilai minimum pada rasio FDR sebesar 71,87 terdapat pada PT. Bank Syariah BRI yang artinya bahwa PT. Bank Syariah BRI kurang baik dalam mengelola rasio FDR karena nilai ini dibawah standar yang ditetapkan, nilai maximum pada rasio FDR sebesar 110,54 terdapat pada PT. Maybank Indonesia Syariah yang artinya bahwa PT. Maybank Indonesia Syariah sangat baik dalam mengelola rasio FDR, serta nilai mean pada rasio FDR sebesar 89,8765. Simpangan baku sebesar 7,37942.

6). Nilai minimum pada rasio NIM sebesar 2,44 terdapat pada PT. Bank Syariah Bukopin yang artinya bahwa PT. Bank Syariah Bukopin tidak cukup baik dalam mengelola rasio NIM karena nilai ini dibawah standar yang ditetapkan, nilai maximum pada rasio NIM sebesar 10,66 terdapat pada PT. Bank Mega Syariah yang artinya bahwa PT. Bank Mega Syariah sangat baik dalam mengelola rasio
NIM, serta nilai mean pada NIM sebesar 5,851. Simpangan baku sebesar 1,89386.

\subsubsection{Uji Asumsi Klasik}

\subsubsection{Uji Normalitas Data}

Uji normalitas data digunakan untuk memperlihatkan bahwa sampel yang diambil dari populasi yang berdistribusi normal yaitu mempunyai pola seperti kurva berbentuk bel yang mempunyai karakteristik (Madli, 2013). Adapun karakteristiknya sebagai berikut:

a). Kurva terkonsentrasi di tengah dan menurun di dua sisi;

b). Kurva berbentuk lonceng (bel) yang bersifat simetris.

Tabel 5.

Hasil Uji Normalitas Data

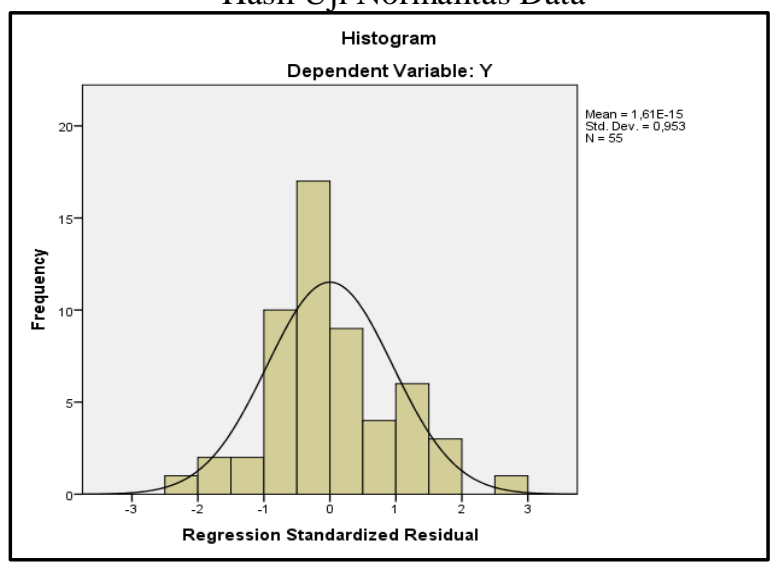

Sumber: Pengolahan data dengan SPSS 24.

Tabel 6.

Hasil Uji One-Sample Kolmogorov-Smirnov

\begin{tabular}{|c|c|c|}
\hline \multicolumn{3}{|c|}{ One-Sample Kolmogorov-Smirnov Test } \\
\hline \multirow{2}{*}{\multicolumn{2}{|c|}{$\mathrm{N}$}} & $\begin{array}{c}\text { Unstandardized } \\
\text { Residual } \\
\end{array}$ \\
\hline & & 55 \\
\hline \multirow{2}{*}{$\begin{array}{l}\text { Normal } \\
\text { Parameters }{ }^{\mathrm{a}} \\
\text {,b }\end{array}$} & Mean & 1,2991 \\
\hline & $\begin{array}{l}\text { Std. } \\
\text { Deviation }\end{array}$ & 1,01846 \\
\hline \multirow{3}{*}{$\begin{array}{l}\text { Most } \\
\text { Extreme } \\
\text { Differences }\end{array}$} & Absolute &, 105 \\
\hline & Positive & ,088 \\
\hline & Negative &,- 105 \\
\hline \multicolumn{2}{|l|}{ Test Statistic } &, 105 \\
\hline \multicolumn{2}{|c|}{ Asymp. Sig. (2-tailed) } & $.200^{c, d}$ \\
\hline \multicolumn{3}{|c|}{ a. Test distribution is Normal. } \\
\hline \multicolumn{3}{|c|}{ b. Calculated from data. } \\
\hline \multicolumn{3}{|c|}{ c. Lilliefors Significance Correction. } \\
\hline \multicolumn{3}{|c|}{ d. This is a lower bound of the true significance. } \\
\hline
\end{tabular}

Sumber: Pengolahan data dengan SPSS 24. 
Berdasarkan hasil uji one-sample kolmogorovsmirnov (Tabel 6) diatas dapat disimpulkan bahwa nilai test statistic sebesar 0,105 serta nilai Asymp. Sig. (2tailed) sebesar 0.200. Nilai Asym. Sig (2-tailed) sebesar $0.200>0.05$, maka dapat disimpulkan bahwa data residual terdistribusi secara normal dan model regresi ini memenuhi asumsi normalitas.

\subsubsection{Uji Multikolinearitas}

Tabel 7.

Hasil Uji Multikolinearitas

\begin{tabular}{|c|c|c|c|}
\hline \multicolumn{4}{|c|}{ Coefficients $^{\mathrm{a}}$} \\
\hline \multirow{2}{*}{\multicolumn{2}{|c|}{ Model }} & \multicolumn{2}{|c|}{ Collinearity Statistics } \\
\hline & & Tolerance & VIF \\
\hline \multirow{5}{*}{1} & $\mathrm{X}_{1}$ &, 920 & 1,087 \\
\hline & $\mathrm{X}_{2}$ &, 773 & 1,293 \\
\hline & $\mathrm{X}_{3}$ &, 810 & 1,235 \\
\hline & $\mathrm{X}_{4}$ & ,995 & 1,005 \\
\hline & $\mathrm{X}_{5}$ & ,914 & 1,094 \\
\hline
\end{tabular}

Sumber: Pengolahan data dengan SPSS 24.

Dari Tabel 7 di atas dapat dilihat bahwa semua varibel independen mempunyai nilai tolerance di atas 0,10 dan nilai VIF di bawah nilai 10, maka dapat disimpulkan bahwa model regresi ini tidak terdapat multikolinearitas.

\subsubsection{Uji Autokorelasi}

Tabel 8.

Hasil Uji Autokorelasi

\begin{tabular}{|c|c|c|c|c|c|}
\hline \multicolumn{6}{|c|}{ Model Summary b } \\
\hline $\begin{array}{c}\text { Mod } \\
\text { el }\end{array}$ & $\mathrm{R}$ & $\begin{array}{c}\mathrm{R} \\
\text { Square }\end{array}$ & $\begin{array}{c}\text { Adjusted R } \\
\text { Square } \\
\end{array}$ & $\begin{array}{l}\text { Std. Error of } \\
\text { the Estimate }\end{array}$ & $\begin{array}{l}\text { Durbin- } \\
\text { Watson }\end{array}$ \\
\hline 1 &, $824^{\mathrm{a}}$ & 680 & 647 &, 60524 & 1,901 \\
\hline \multicolumn{6}{|c|}{ a. Predictors: (Constant), $\mathrm{X}_{5}, \mathrm{X}_{4}, \mathrm{X}_{1}, \mathrm{X}_{3}, \mathrm{X}_{2}$} \\
\hline \multicolumn{6}{|c|}{ b. Dependent Variable: Y } \\
\hline
\end{tabular}

Sumber: Pengolahan data dengan SPSS 24.

Berdasarkan hasil uji autokorelasi (Tabel 8) di atas dapat disimpulkan bahwa nilai Durbin Watson sebesar 1,901, nilai tabel signifikansi 5\%, jumlah sampel 55 maka $\mathrm{T}=55$, sedangkan jumlah variabel dependen dan independen sebanyak 6 maka $\mathrm{k}=6$. Berdasarkan $\mathrm{T}$ dan $\mathrm{k}$ maka dapat diperoleh nilai $\mathrm{dl}$ sebesar 1.37431 dan nilai du sebesar 1.76807. Batas atas nilai du adalah $d u=(4-d u)$ sama dengan 2,23193. Sehingga dapat disimpulkan bahwa model ini bebas dari autokorelasi, karena nilai Durbin Watson berada diantara nilai du dengan nilai $4-\mathrm{du}$.

\subsubsection{Uji Heterokedastisitas}

Tabel 9.

Hasil Uji Heterokedastisitas

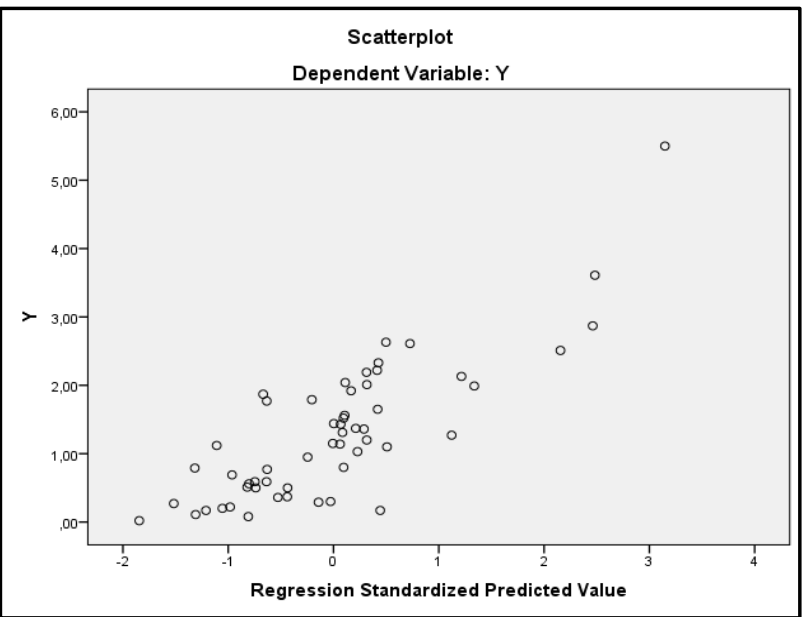

Sumber: Pengolahan data dengan SPSS 24.

Berdasarkan hasil uji heterokedastisitas (Tabel 4.6) di atas dapat disimpulkan bahwa titik-titik menyebar dan tidak membentuk suatu pola yang jelas, dengan demikian dapat disimpulkan bahwa model regresi ini bebas dari heterokedastisitas.

\subsubsection{Uji Regresi Berganda}

Tabel 10 .

Hasil Uji Regresi

\begin{tabular}{|c|c|c|c|c|c|}
\hline \multicolumn{6}{|c|}{ Coefficients ${ }^{\mathrm{a}}$} \\
\hline \multirow{2}{*}{ Model } & \multicolumn{2}{|c|}{$\begin{array}{c}\text { Unstandardized } \\
\text { Coefficients }\end{array}$} & $\begin{array}{l}\text { Standa } \\
\text { rdized } \\
\text { Coeffi }\end{array}$ & \multirow{2}{*}{$\mathrm{t}$} & \multirow{2}{*}{ Sig. } \\
\hline & B & $\begin{array}{l}\text { Std. } \\
\text { Error }\end{array}$ & Beta & & \\
\hline (Constant) & 1,843 & 1,497 & & 1,231 &, 224 \\
\hline $\mathrm{X}_{1}$ &,- 012 & 054 &,- 018 &,- 218 &, 828 \\
\hline $\mathrm{X}_{2}$ &,- 43 &, 011 &,- 346 &,- 3763 &, 000 \\
\hline $\mathrm{X}_{3}$ &, 040 &, 007 &, 532 & 5,916 &, 000 \\
\hline $\mathrm{X}_{4}$ &, 021 &, 011 &, 152 & 1,875 &, 067 \\
\hline$X_{5}$ &, 098 &, 045 &, 182 & 2,157 &, 036 \\
\hline
\end{tabular}

Sumber: Pengolahan data dengan SPSS 24.

Berdasarkan hasil uji regresi berganda (Tabel 10) di atas, berikut ini model persamaan regresi berganda penelitian ini :

$\mathrm{Y}=1,843-0,012 \mathrm{X}_{1}-0,043 \mathrm{X}_{2}+0,040 \mathrm{X}_{3}+0,021 \mathrm{X}_{4}+$ $0,098 \mathrm{X}_{5}+\mathrm{e}$ 
Dari model persamaan regresi penelitian diatas dapat diuraikan sebagai berikut:

1). Nilai konstanta bertanda positif yaitu 1,843 . Ini berarti apabila rasio NPF, BOPO, CAR FDR dan NIM naik $1 \%$ maka akan menaikkan nilai ROA sebesar $1,843 \%$.

2). Nilai koefisien NPF bertanda negatif yaitu $-0,012$. Ini berarti apabila NPF naik $1 \%$ maka akan menurunkan nilai ROA sebesar 0,012\%.

3). Nilai koefisien BOPO bertanda negatif yaitu 0,043. Ini berarti apabila BOPO naik $1 \%$ maka akan menurunkan nilai ROA sebesar 0,043\%.

4). Nilai koefisien CAR bertanda positif yaitu 0,040 . Ini berarti apabila CAR naik $1 \%$ maka akan menaikkan nilai ROA sebesar $0,040 \%$.

5). Nilai koefisien FDR bertanda positif yaitu 0,021 . Ini berarti apabila FDR naik 1\% maka akan menaikkan nilai ROA sebesar $0,021 \%$.

6).Nilai koefisien NIM bertanda positif yaitu 0,098. Ini berarti apabila NIM naik $1 \%$ maka akan menaikkan nilai ROA sebesar $0,098 \%$.

\subsubsection{Uji Hipotesis}

\section{a). Uji-F}

Tabel 11.

Hasil Uji-F

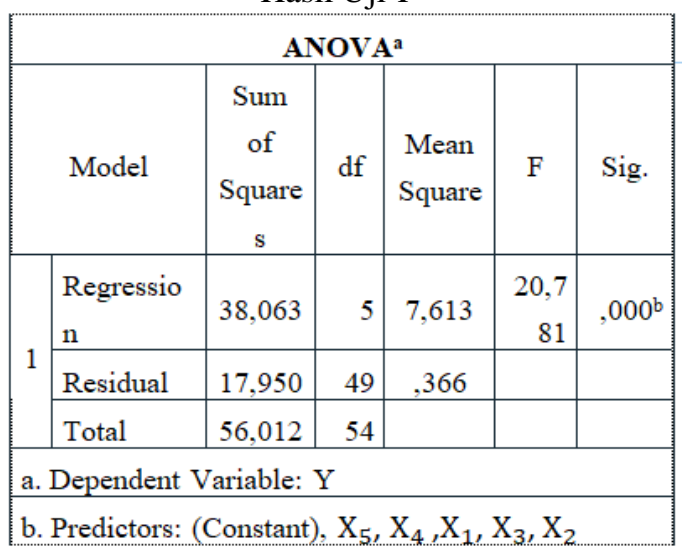

Sumber: Pengolahan data dengan SPSS 24.

Berdasarkan hasil uji $\mathrm{F}$ (Tabel 11) di atas dapat disimpulkan bahwa nilai $F_{\text {hitung }}$ sebesar 20,781 dengan siginfikansi sebesar 0,000 . Karena nilai signifikansi sebesar $0,000<0,05$ maka model regresi ini dapat dipergunakan untuk memprediksi Perubahan Laba atau dapat dikatakan bahwa variabel independen yaitu NPF, BOPO, CAR, FDR dan NIM secara simultan berpengaruh terhadap variabel dependen ROA.

Tabel 12.

Hasil Uji $F_{\text {tabel }}$

\begin{tabular}{|c|c|c|c|}
\hline Variabel & $\mathbf{F}_{\text {hitung }}$ & $\mathbf{F}_{\text {tabel }}$ & $\begin{array}{c}\text { Hasil } \\
\text { Hipotesis }\end{array}$ \\
\hline $\mathrm{X}_{1}, \mathrm{X}_{2}, \mathrm{X}_{3}, \mathrm{X}_{4}$ & 20,781 & 2,40 & $\mathrm{H}_{0}$ Ditolak \\
\hline
\end{tabular}

Sumber: Pengolahan data dengan SPSS 24
Berdasarkan hasil uji $F_{\text {tabel }}$ (Tabel 12) dapat disimpulkan bahwa nilai $F_{\text {tabel }}$ sebesar 2.29. Nilai ini diperoleh dari nilai df1 sebesar 5, nilai df2 sebesar 49 . Dengan demikian variabel NPF, BOPO, CAR, FDR dan NIM secara simultan berpengaruh terhadap ROA, karena nilai $\mathrm{F}_{\text {hitung }} 20,781>2,40 \mathrm{~F}_{\text {tabel }}$.

\section{b). Uji-t}

Tabel 13

Hasil Uji-t

\begin{tabular}{|c|c|c|c|c|c|}
\hline \multicolumn{6}{|c|}{ Coefficients $^{\mathrm{a}}$} \\
\hline \multirow[t]{2}{*}{ Model } & \multicolumn{2}{|c|}{$\begin{array}{l}\text { Unstandardiz } \\
\text { ed } \\
\text { Coefficients }\end{array}$} & $\begin{array}{l}\text { Standardiz } \\
\text { ed } \\
\text { Coefficien }\end{array}$ & \multirow[t]{2}{*}{$\mathrm{t}$} & \multirow[t]{2}{*}{ Sig. } \\
\hline & B & $\begin{array}{l}\text { Std. } \\
\text { Error }\end{array}$ & Beta & & \\
\hline (Constant) & $\begin{array}{r}1,84 \\
3 \\
\end{array}$ & 1,497 & & 1,231 &, 224 \\
\hline $\mathrm{X}_{1}$ &,- 012 &, 054 &,- 018 &,- 218 &, 828 \\
\hline $\mathrm{X}_{2}$ & -.43 &, 011 &,- 346 & $\begin{array}{r}- \\
3.763\end{array}$ &, 000 \\
\hline $\mathrm{X}_{3}$ &, 040 &, 007 &, 532 & 5,916 &, 000 \\
\hline $\mathrm{X}_{4}$ &, 021 &, 011 &, 152 & 1,875 &, 067 \\
\hline $\mathrm{X}_{5}$ &, 098 &, 045 &, 182 & 2,157 &, 036 \\
\hline
\end{tabular}

Sumber: Pengolahan data dengan SPSS 24.

Berdasarkan hasil Uji-t (Tabel 13) dapat disimpulkan bahwa :

1. Pada variabel NPF $\left(\mathrm{X}_{1}\right)$ dengan ingkat signifikansi sebesar 0,828 tidak berpengaruh terhadap ROA. Hal ini dikarenakan tingkat signifikansi NPF $0,828>$ 0,05 .

2. Pada variabel BOPO $\left(\mathrm{X}_{2}\right)$ dengan tingkat signifikansi sebesar 0,000 berpengaruh terhadap ROA. Hal ini dikarenakan tingkat signifikansi BOPO $0,000<0,05$.

3. Pada variabel CAR $\left(\mathrm{X}_{3}\right)$ dengan tingkat signifikansi sebesar 0,000 berpengaruh terhadap ROA. Hal ini dikarenakan tingkat signifikansi CAR yaitu 0,000 $<0,05$.

4. Pada variabel FDR $\left(\mathrm{X}_{4}\right)$ dengan tingkat signifikansi sebesar 0,067 tidak berpengaruh terhadap ROA. Hal ini dikarenakan tingkat signifikansi FDR 0,067 > 0,05 .

5. Pada variabel NIM $\left(\mathrm{X}_{5}\right)$ dengan tingkat signifikansi sebesar 0,036 berpengaruh terhadap ROA. Hal ini dikarenakan tingkat signifikansi NIM 0,036 $<0,05$. 
Tabel 14.

Hasil Uji $t_{\text {tabel }}$

\begin{tabular}{|c|c|c|c|}
\hline Variabel & $\mathbf{t}_{\text {hitung }}$ & $\mathbf{T}_{\text {tabel }}$ & Hasil Hipotesis \\
\hline $\mathrm{X}_{1}$ &, 218 & 2,004 & $\mathrm{H}_{0}$ Diterima \\
\hline $\mathrm{X}_{2}$ & 3,763 & 2,004 & $\mathrm{H}_{0}$ Ditolak \\
\hline $\mathrm{X}_{3}$ & 5,916 & 2,004 & $\mathrm{H}_{0}$ Ditolak \\
\hline $\mathrm{X}_{4}$ & 1,875 & 2,004 & $\mathrm{H}_{0}$ Diterima \\
\hline $\mathrm{X}_{5}$ & 2,157 & 2,004 & $\mathrm{H}_{0}$ Ditolak \\
\hline
\end{tabular}

Sumber: Pengolahan data dengan SPSS 24.

Tingkat signifikan Uji-t adalah sebesar 0,05 dengan derajat kebebasan df sebesar 55. Pada Tabel 14 terlihat bahwa :

1. Pada rasio NPF nilai $t_{\text {hitung }}<$ nilai $t_{\text {tabel }}$ yaitu 0,218 $<2,004$. Hal ini dapat disimpulkan bahwa NPF tidak berpengaruh terhadap variabel ROA .

2. Pada rasio BOPO nilai $t_{\text {hitung }}>t_{\text {tabel }}$ yaitu $3,763>$ 2,004. Hal ini dapat disimpulkan bahwa BOPO berpengaruh terhadap variabel ROA.

3. Pada rasio CAR nilai $t_{\text {hitung }}>t_{\text {tabel }}$ yaitu 5,916 > 2,004. Hal ini dapat disimpulkan bahwa rasio CAR berpengaruh terhadap variabel ROA.

4. Pada rasio FDR Nilai $t_{\text {hitung }}<t_{\text {tabel }}$ FDR yaitu 1,875 $<2,004$. Hal ini dapat disimpulkan bahwa rasio FDR tidak berpengaruh terhadap variabel ROA.

5. Pada rasio NIM nilai $t_{\text {hitung }}>t_{\text {tabel }}$ NIM yaitu 2,157 $>$ 2,004. Hal ini dapat disimpulkan bahwa rasio NIM berpengaruh terhadap variabel ROA

\subsubsection{Uji Koefisien Determinasi}

Tabel 15.

Hasil Uji Koefisien Determinasi

\begin{tabular}{|c|c|c|c|c|r|}
\hline \multicolumn{7}{|c|}{ Model Summary $^{\mathrm{b}}$} \\
\hline $\begin{array}{c}\text { Mode } \\
1\end{array}$ & $\mathrm{R}$ & $\begin{array}{c}\mathrm{R} \\
\text { Square }\end{array}$ & $\begin{array}{c}\text { Adjust } \\
\text { ed R } \\
\text { Square }\end{array}$ & $\begin{array}{c}\text { Std. Error } \\
\text { of the } \\
\text { Estimate }\end{array}$ & $\begin{array}{c}\text { Durbin- } \\
\text { Watson }\end{array}$ \\
\hline 1 &, $824^{\mathrm{a}}$ &, 680 &, 647 &, 60524 & 1,901 \\
\hline
\end{tabular}

Sumber: Pengolahan data dengan SPSS 24.

Berdasarkan hasil uji koefisien determinasi pada Tabel 15 di atas dapat disimpulkan bahwa nilai koefisien penentu ( $R$ Square) variabel independen dengan variabel dependen adalah sebesar 0,680. Sementara itu kriteria penilaian korelasi menurut Sugiyono (2016) adalah sebagai berikut:
Tabel 16

Kriteria Korelasi

\begin{tabular}{|c|c|c|c|}
\hline Variabel & $\mathbf{t}_{\text {hitung }}$ & $\mathbf{T}_{\text {tabel }}$ & Hasil Hipotesis \\
\hline $\mathrm{X}_{1}$ &, 218 & 2,004 & $\mathrm{H}_{0}$ Diterima \\
\hline $\mathrm{X}_{2}$ & 3,763 & 2,004 & $\mathrm{H}_{0}$ Ditolak \\
\hline $\mathrm{X}_{3}$ & 5,916 & 2,004 & $\mathrm{H}_{0}$ Ditolak \\
\hline $\mathrm{X}_{4}$ & 1,875 & 2,004 & $\mathrm{H}_{0}$ Diterima \\
\hline $\mathrm{X}_{5}$ & 2,157 & 2,004 & $\mathrm{H}_{0}$ Ditolak \\
\hline
\end{tabular}

Sumber : Sugiyono (2016)

Pada Tabel 16 terlihat nilai $R$ Square adalah sebesar 0,680, dimana interval koefisien angka ini berada pada antara 0,60-0,799 dengan tingkat hubungannya adalah kuat.

\subsection{Pembahasan}

\subsubsection{Pengaruh NPF, BOPO, CAR, FDR dan NIM terhadap ROA}

Berdasarkan hasil uji hipotesis pada Tabel 4.8 di ketahui bahwa nilai $F_{\text {hitung }}$ sebesar 20,781 dengan siginfikansi $0,000<0,005$, dengan demikian dapat disimpulkan bahwa NPF, BOPO, CAR, FDR dan NIM secara simultan berpengaruh terhadap ROA dan berdasarkan hasil uji $F_{\text {tabel }}$ (Tabel 4.9) dapat diketahui bahwa nilai $F_{\text {tabel }}$ sebesar 2,40, dimana nilai ini diperoleh dari nilai df1 sebesar 5, pada penelitian ini bahwa NPF, BOPO, CAR, FDR dan NIM secara simultan berpengaruh terhadap ROA, karena nilai $F_{\text {hitung }}$ $20,781>F_{\text {tabel }} 2,40$. Hasil ini sejalan dengan penelitian yang dilakukan oleh Dwi Priyanto Agung Raharjo (2014 ); Luh Eprima Dewi (2015) Anti Suryani (2016); Sumarlin (2016); Nuri Zulfah Hijriyani dan Setiawan (2017); Salman Alfarisi (2017); Mia Agustina (2018).

\subsubsection{Pengaruh NPF terhadap ROA}

Berdasarkan hasil pengujian regresi linear berganda (tabel 4.11) nilai $\mathrm{t}_{\text {hitung }} 0,218<\mathrm{t}_{\text {tabel }} 2,004$. Hal ini dapat disimpulkan bahwa variabel NPF tidak berpengaruh terhadap ROA. Atau dapat dibuktikan dengan tingkat signifikansi variabel NPF 0,828>0,05 yang berarti variabel NPF tidak berpengaruh terhadap ROA. Semakin besar nilai NPF maka akan menurunkan laba, semakin tinggi rasio ini, semakin buruk kualitas kredit yang menyebabkan jumlah kredit bermasalah semakin besar sehingga dapat menyebabkan kemungkinan suatu bank dalam kondisi bermasalah semakin besar (Almilia dan Herdiningtyas, 2005).

Hal ini dapat dibuktikan bahwa dari 11 bank umum syariah di indonesia dari tahun 2013-2017 hanya 1 bank yang rata-rata rasio NPF mendekati kolektibilitas 5 yaitu Bank Victoria Syariah yaitu sebesar 4,26\%, sedangkan yang lainnya seperti Bank Syariah Madiri 3,29\%, Bank Syariah Muamalat Indonesia 2,96\%, Bank Syariah BNI 1,26\%, Bank Syariah BRI 3,74\%, Bank Syariah Mega Indonesia 
3,48\%, Bank Jabar dan Banten Syariah 0,82\%,Bank Panin Syariah 1,94\%, Bank Syariah Bukopin 3,74\%, Bank BCA Syariah 0,26\% dan Maybank Indonesia Syariah 3,40\%.

Penelitian ini didukung oleh penelitian yang dilakukan oleh Hijriyani, Z. Nuri dan Setiawan (2017), Anti Suryani (2016); Fatah dan Rahadian (2018) Non Performing Financing (NPF) tidak berpemgaruh terhadap Return On Asset (ROA), tetapi penelitian ini tidak didukung oleh penelitian yang dilakukan oleh Salman, A. Parisi (2017; Raharjo (2014); Sumarlin (2016); Sutrisno (2017) dan Hafidz dan Safira (2018); Agustina (2018) yang menyatakan bahwa Non Performing Financing (NPF) berpemgaruh terhadap Return On Asset (ROA).

\subsubsection{Pengaruh BOPO terhadap ROA}

Berdasarkan hasil pengujian regresi linear berganda (Tabel 4.11) nilai $\mathrm{t}_{\text {hitung }} 3,763>\mathrm{t}_{\text {tabel }} 2,004$. Hal ini dapat disimpulkan bahwa variabel BOPO berpengaruh terhadap ROA. Hal ini juga dapat dibuktikan dengan tingkat signifikansi variabel BOPO $0,000<0,05$ yang berarti variabel BOPO berpengaruh terhadap ROA. . Semakin rendah tingkat rasio BOPO berarti semakin baik kinerja managemen bank tersebut, karena lebih efisien dalam menggunakan sumber daya yang ada pada perusahaan (Rivai, 2007). Hal ini dibuktikan bahwa 3 dari 11 Bank Umum Syariah di Indonesia tahun 2013-2017 yang memiliki rata-rata rasio di atas 93\% yaitu Bank Syariah Muamalat Indonesia yaitu sebesar 96,80\%, Bank Syariah BRI sebesar 94,11\% dan Bank Syariah Bukopin sebesar $93,97 \%$.

Penelitian ini didukung oleh penelitian yang dilakukan oleh Raharjo (2014); Dewi, L. Eprima (2015); Arini (2015), Anti Suryani (2016); Hijriyani, Z. Nuri dan Setiawan (2017); Sumarlin (2016); Salman, A. Parisi (2017); Sutrisno (2017); Fatah dan Rahadian (2018) bahwa Biaya Operasional dan Pendapatan Operasional (BOPO) berpemgaruh terhadap Return On Asset (ROA).

\subsubsection{Pengaruh CAR terhadap ROA}

Berdasarkan hasil pengujian regresi linear berganda (Tabel 4.11) nilai $\mathrm{t}_{\text {hitung }} 5,916>\mathrm{t}_{\text {tabel }} 2,004$. Hal ini dapat disimpulkan bahwa variabel CAR berpengaruh terhadap ROA. Hal ini juga dapat dibuktikan dengan tingkat signifikansi variabel CAR $0,000<0,05$ yang berarti variabel CAR berpengaruh terhadap ROA. Semakin tinggi CAR maka semakin tinggi modal sendiri yang digunakan untuk mendanai aktiva produktifnya atau menutup kerugian dari penanaman aktiva (Fahmi, 2014). Hal ini dapat dibuktikan bahwa dari 11 Bank Umum Syariah di Indonesia dari tahun 2013-2017 hanya ada 1 Bank yang memiliki rata-rata CAR di bawah $8 \%$ yaitu Bank Syariah Bukopin yaitu sebesar $4,10 \%$, sedangkan 10 Bank umum syariah lainnya memiliki rata-rata rasio di atas 8\% seperti Bank Syariah Mandiri 14,9\%, Bank Syariah Muamalat Indonesia 13,26\%, Bank Syariah
BNI 16,61\%, Bank Syariah BRI 16,45\%, Bank Syariah Mega Indonesia 19,34\%, Bank Jabar dan Banten Syariah 17,20\%, Bank Panin Syariah 19,30\%, Bank Victoria Syariah 17,02\%, Bank BCA Syariah 30,48\% dan Maybank Indonesia Syariah 67,17\%.

Penelitian ini didukung oleh penelitian yang dilakukan oleh Raharjo (2014); Purnamasari dan Ariyanto (2016); Warsa dan I Ketut Mustanda (2016); Salman, A. Parisi (2017); Hafidz dan Safira (2018); Sumarlin (2016); Agustina (2018) bahwa Capital Adequacy Ratio (CAR) berpengaruh terhadap Return On Asset (ROA). Namun penelitian ini tidak didukung oleh penelitian yang dilakukan Anti Suryani (2016); Sutrisno (2017); Fatah dan Rahadian (2018) bahwa Capital Adequacy Ratio (CAR) tidak berpengaruh terhadap Return On Asset (ROA).

\subsubsection{Pengaruh FDR terhadap ROA}

Berdasarkan hasil pengujian regresi linear berganda (Tabel 4.11) nilai $\mathrm{t}_{\text {hitung }} 1,875<\mathrm{t}_{\text {tabel }} 2,004$. Hal ini dapat disimpulkan bahwa variabel FDR tidak berpengaruh terhadap ROA. Atau dapat dibuktikan dengan tingkat signifikansi variabel FDR 0,067>0,05 yang berarti variabel FDR tidak berpengaruh terhadap ROA. Variabel FDR tidak berpengaruhnya terhadap Return On Asset (ROA) dikarenakan selama periode penelitian bank tidak berlebihan dalam menyalurkan kreditnya, hal ini dibuktikan bahwa dari 11 Bank Umum Syariah di Indonesia tahun 2013-2017 hanya 1 Bank Umum Syariah yang memiliki rata-rata rasio FDR dibawah $92 \%$ yaitu Bank Syariah Mega Indonesia yaitu sebesar 94,35\%. Penelitian ini didukung oleh penelitian yang dilakukan oleh Hijriyani, Z. Nuri dan Setiawan (2017); Fatah dan Rahadian (2018) bahwa Financing to Deposit Ratio (FDR) tidak berpengaruh berpengaruh terhadap Return On Asset (ROA). Namun penelitian ini tidak didukung oleh penelitian yang dilakukan Salman, A. Parisi (2017); Sumarlin (2016) ) dan Sutrisno (2017) bahwa Financing to Deposit Ratio (FDR) berpengaruh terhadap Return On Asset (ROA).

\subsubsection{Pengaruh NIM terhadap ROA}

Berdasarkan hasil pengujian regresi linear berganda (Tabel 4.11) nilai $t_{\text {hitung }} 2,157>t_{\text {tabel }} 2,004$. Hal ini dapat disimpulkan bahwa variabel NIM berpengaruh terhadap ROA. Atau dapat dibuktikan dengan tingkat signifikansi variabel NIM $0,036<0,05$ yang berarti variabel NIM berpengaruh terhadap ROA. Semakin besar rasio ini maka bank akan menikmati peningkatan pendapatan bunga dan keefektifan manajemen bank dalam mengelola aktiva produktifnya sehingga memungkinkan bank dalam kondisi tidak bermasalah (Pandia, 2012).

Hal ini dapat dibuktikan bahwa 5 dari 11 Bank Umum Syariah di Indonesia tahun 2013-2017 yang memiliki rata-rata rasio NIM di bawah $6 \%$ yaitu Bank Syariah Muamalat Indonesia sebesar 3,56\%, Bank Panin Syariah sebesar 4,91\%, Bank Syariah Bukopin sebesar 3,10\% dan Bank Penelitian ini didukung oleh penelitian yang dilakukan oleh Raharjo (2014); Dewi, 
L. Eprima (2015); Anti Suryani (2016); Agustina (2018) bahwa Net Interest Margin (NIM) berpengaruh terhadap Return On Asset (ROA). Namun penelitian ini tidak didukung oleh penelitian yang dilakukan oleh Purnamasari dan Ariyanto (2016) bahwa Net Interest Margin (NIM) tidak berpengaruh terhadap Return On Asset (ROA).

\section{SIMPULAN DAN SARAN}

\subsection{Simpulan}

Berdasarkan hasil analisis dan pembahasan yang telah dilakukan sebagaimana tersebut diatas, maka dapat ditarik simpulan sebagai berikut:

1). Variabel NPF, BOPO, CAR, FDR dan NIM secara simultan berpengaruh terhadap return on asset (ROA).

2). Variabel Non Performing Financing (NPF) tidak berpengaruh terhadap Return On Asset (ROA). Semakin tinggi nilai NPF maka akan menurunkan nilai ROA, sehingga akan semakin buruk kualitas kredit yang menyebabkan jumlah kredit bermasalah semakin besar dan dapat menyebabkan kemungkinan suatu bank dalam kondisi bermasalah semakin besar.

3). Variabel Biaya operasional dan pendapatan operasional (BOPO) berpengaruh terhadap return on asset (ROA). Berpengaruhnya BOPO terhadap ROA menunjukkan bank sangat mempertimbangkan efisiensi operasionalnya dengan memperhatikan biaya yang dikeluarkan dan pendapatan yang diterima. Bank harus mengontrol efisiensi operasionalnya agar bisa meningkatkan laba, hal ini dibuktikan dengan nilai rata-rata BOPO pada keseluruhan bank sebesar $88,54 \%$ dimana angka ini sesuai dengan standar yang ditetapkan.

4). Variabel Capital Adequacy Ratio (CAR) berpengaruh terhadap ROA. Berpengaruhnya CAR terhadap ROA dikarenakan bank telah mengoptimalkan modal yang dimilikinya, hal ini dibuktikan dengan tingginya rata-rata CAR pada keseluruhan bank yaitu sebesar 20,37 \%, dimana angka ini jauh diatas standar yang ditetapkan.

5). Variabel Financing to Deposit Ratio (FDR) tidak berpengaruh terhadap ROA. Variabel FDR tidak berpengaruhnya terhadap ROA dikarenakan bank tidak berlebihan dalam menyalurkan kreditnya, hal ini dibuktikan dengan nilai rata-rata FDR pada keseluruhan bank yaitu sebesar 89,87 \%, dimana angka ini aman untuk menjaga likuiditas perbankan karena berada pada standar yang ditetapkan.

6). variabel Net Interest Margin (NIM) berpengaruh terhadap ROA. Semakin besar nilai NIM maka akan meningkatkan pendapatan bunga atau aktiva produktif yang dikelola sehingga kemungkinan suatu bank dalam kondisi bermasalah semakin kecil.

\subsection{Keterbatasan Penelitian}

Peneliti telah berusaha dengan segenap upaya dalam melakukan penelitian ini, namun pada pelaksanaannya peneliti menemukan berbagai kendala yang menimbulkan keterbatasan pada penelitian ini, diantaranya adalah sebagai berikut:

1). Keterbatasan populasi dan sampel penelitian yang hanya meliputi Bank Umum Syariah sebanyak 11 Bank hal ini memungkinkan tidak bisa lebih akurat dan menyeluruh dalam memprediksi faktor apa saja yang mempengaruhi variabel NPF, BOPO, CAR, FDR dan NIM terhadap return on asset (ROA).

2). Keterbatasan periode pengamatan yang hanya mengambil lingkup selama 5 tahun, sehingga hasil penelitian ini menunjukkan bahwa beberapa rasio keuangan memiliki pengaruh yang tidak sesuai dengan teori yang ada terhadap return on asset (ROA).

\subsection{Saran}

Peneliti bermaksud memberikan beberapa saran berdasarkan penelitian yang telah dilakukan, yaitu:

(1). Bagi Peneliti selanjutnya sebaiknya untuk meneliti perbandingan Bank Konvensional dan Bank Umum Syariah di Indonesia dan/atau perbankan yang terdaftar di Bursa Efek Indonesia (BEI) dengan tujuan melihat pengaruh variabel yang bersangkutan agar lebih bisa mencerminkan kondisi perbankan.

(2). Periode penelitian diharapkan lebih panjang sehingga dapat mencerminkan kondisi bank dalam jangka panjang.

(3). Jika memungkinkan menambah variabel-variabel lainnya yang dapat memperkuat pengaruh independen terhadap variabel dependen, seperti misalnya manajemen laba, pembagian deviden, likuiditas, jenis pembiayaan sehingga bisa menambah pengetahuan lebih luas lagi.

\section{DAFTAR REFERENSI}

Agustina. 2018. Analisis Pengaruh LDR, NPL, NIM dan CAR terhadap ROA Pada Perbankan yang terdaftar di Bursa Efek Indonesia (BEI) Periode 2012-2016. Ejournal Administrasi Bisnis. 6 (2): 555-566 ISSN 2355-5408.

Anti Suryani. 2016. Pengaruh Rasio CAR, BOPO, LDR, NIM dan NPL terhadap Return On Asset (ROA) (Studi Pada Bank Umum yang Terdaftar di Bursa Efek Indonesia Periode 2012-2014). Vol. 33, Nomor. 1.

Arikunto. 2010. Prosedur Penelitian Suatu Pendekatan Praktik, Jakarta: Rineka Cipta. 
Arini. 2015. Pengaruh Pembiayaan dan Efisiensi Terhadap Profitabilitas Bank Umum Syariah. Vol.1, Nomor 1.

Bank Indonesia. 2001. Surat Edaran Nomor/3/30/DPNP tanggal 14 Desember 2001 tentang Biaya Operasional Pendapatan Operasional (BOPO).

Bank Indonesia. 2004. Surat Edaran Nomor 6/23/DPNP tahun 2004 tentang Perhitungan Rasio Keuangan.

Bank Indonesia. 2011. Peraturan Bank Indonesia Nomor. 13/1/PBI/2011 tentang penilaian tingkat kesehatan Bank Umum. Jakarta. hlm.6-8.

Bank Indonesia. 2013. Laporan Perkembangan Perbankan Syariah. Jakarta: Bank Indonesia.

Bank Indonesia. 2018. Statistik Perbankan Syariah (Jakarta) diperoleh pada 10 Juli 2018 dari http//www.bi.go.id/idstatistikprtbankansyariah/d efault aspx.

Dendawijaya. 2009. Manajemen Perbankan, Jakarta: Ghalia Indonesia.

Dewi, L. Eprima. 2015. Analisis Pengaruh NIM, BOPO, LDR, dan NPL Terhadap Profitabilitas Bank Umum Swasta Periode 2009-2013. E Journal Vol. 3, Nomor. 1.

Fahmi. 2012. Analisis Laporan Keuangan. Cetakan Ke 2. Bandung: Alfabeta.

Fatah dan Rahadian. 2018. Pengaruh CAR, NPF, FDR dan BOPO Terhadap ROA Perbankan Syariah. Vol. 5, Nomor. 1. Page 268. ISSN:23559357.

Ghozali. 2011. Aplikasi Analisis Multivariate dengan Program SPSS. Cetakan ke IV. Semarang: Badan Penerbit UNDIP.

Hafidz dan Safira. 2018. Analisis Pengaruh Manajemen Risiko terhadap Profitabilitas (Studi Komparatif Pada Bank Umum Konvensional dan Bank Umum Syariah yang terdaftar di OJK Periode 2012-2015). Vol. 11, Nomor 1.

Harahap. 2009. Analisis Kritis Atas Laporan Keuangan. Jakarta.

Harlyan, Ledhyane Ika. 2012. Statistik. Malang: Universitas Brawijaya.

Herdiningtyas. 2005. Analisa Rasio CAMEL Terhadap Prediksi Kondisi Bermasalah pada Lembaga Perbankan periode 2000-2002. Jurnal Akuntansi dan Keuangan. Vol. 7, Nomor 2.

Hijriyani, Z. Nuri dan Setiawan. 2017. Analisis Profitabilitas Perbankan Syariah di Indonesia Sebagai dampak dari Efisiensi Operasional. Jurnal Kajian Akuntansi. Volume 1.

Ikatan Akuntan Indonesia. 2012. Standar Akuntansi Keuangan, Jakarta: Salemba Empat.
Indriantoro dan Supomo. 2002. Metodologi Penelitian Bisnis Untuk Akuntansi dan Manajemen. Yogyakarta: Universitas Gajah Mada.

Ismail. 2011. Manajemen Perbankan: Dari Teori Menuju Aplikasi. Cetakan ke Dua. Jakarta: Kencana.

Kartikahadi. 2012. Akuntansi Keuangan Berdasarkan SAK Berbasis IFRS, Jakarta: Salemba Empat.

Kasmir. 2012. Analisis Laporan Keuangan. Jakarta: Raja Grafindo Persada.

Kasmir. 2014. Dasar-Dasar Perbankan. Edisi Revisi Cetakan Ke 12. Jakarta: Raja Grafindo Persada.

Kusuma. 2006. Dampak Manajemen Laba Terhadap Relevansi Informasi Akuntansi : Bukti Empiris Dari Indonesia, Jurnal Akuntansi dan Keuangan, Vol. 8, Nomor 1.

Madli. 2013. Pengaruh Ukuran Perusahaan, Return On Asset, Debt To Equity Ratio Terhadap Manajemen Laba Pada Perusahaan Properti dan Real Eatate Yang Terdaftar di Bursa Efek Indonesia Tahun 2008-2012. Riau: Universitas Maritim Raja Ali Haji.

Narbuko, Cholid dan H. Adi Achmadi. 2003. Metodologi Penelitian, Jakarta: Bumi Aksara.

Pandia. 2012. Manajemen Dana dan Kesehatan Bank. Jakarta: Rineka Cipta.

Peraturan Bank Indonesia Nomor 31/21/PBI/2001 Tentang Kewajiban Modal Minimum Bank.

Peraturan Bank Indonesia Nomor 10/15/PBI/2008 Tentang Kewajiban Modal Minimum Bank Umum.

Peraturan Bank Indonesia Nomor 17/11/PBI/2015 Tentang Perubahan Atas Peraturan Bank Indonesia Nomor 15/15/PBI/2013 Tentang Giro Wajib Minimum Bank Umum Dalam Rupiah dan Valuta Asing Bagi Bank Umum Konvensional.

Peraturan Bank Indonesia Nomor 18/14/PBI/2016 Tentang Perubahan Keempat Atas Peraturan Bank Indonesia Nomor 15/15/PBI/2013 Tentang Giro Wajib Minimum Bank Umum Dalam Rupiah dan Valuta Asing Bagi Bank Umum.

Pernyataan standar akuntansi keuangan (PSAK) Nomor 31 Tahun 2009 tentang perbankan.

Purnamasari dan Ariyanto. 2016. Analisis Perbandingan Kinerja Keuangan Bank Konvensional dan Bank Syariah Periode 20102014. ISSN: 2302-8556 E-Jurnal Vol. 15, Nomor 1.

Raharjo. 2014. Pengaruh Rasio CAR, NPL, LDR, BOPO, dan NIM terhadap Kinerja Bank Umum di Indonesia. Vol. 15, Nomor. 2. 
Rivai, Veithzal. 2007. Bank and Financial Institution Mangement. Jakarta : PT. Raja Grafindo Persada.

Ross, Stepen A. 1997. The Determination Of Financial Structure The Incentive Signaling Approach. The Bell Journal Of Economics.

Salman, A. Parisi. 2017. Determinan Kinerja Keuangan Bank Umum Syariah di Indonesia. Vol. 2, Nomor 1. ISSN: 2527-3434.

Samsudi. 2009. Desain Penelitian Pendidikan. Semarang: Unnes Press..

Sugiyono. 2016. Metode Penelitian Kuantitatif Kualitatif dan Riset \& Development. Bandung: Alfabeta.

Sumarlin. 2016. Analisis Pengaruh INFLASI, CAR, FDR, BOPO, dan NPF Terhadap Profitabilitas Perbankan Syariah.Vol. 6, Nomor 2.

Sutrisno. 2017. Risiko dan Kinerja Bank Perkreditan Rakyat (Studi Perbandingan antara BPR Syariah dengan Konvensional di Indonesia). Vol. 11, Nomor 2.

Suwiknyo. 2010. Jasa-jasa Perbankan Syari'ah, Pustaka Pelajar, Yogyakarta.

Uma Sekaran. 2012. Research Methods For Business Edisi 1 and 2. Salemba Empat:Jakarta.

Umam. 2013. Manajemen Perbankan Syariah. Bandung: Pustaka Setia.

Undan-Undang Nomor 10 Tahun 1998. Tentang Perubahan Terhadap UU No.7 Tahun 1992 tentang perbankan. Jakarta

Wardana. 2015. Analisis pengaruh CAR, FDR, BOPO dan SIZE terhadap Profitabilitas Pada Bank Umum Syariah di Indonesia 2011-2014.

Warsa dan I Ketut Mustanda. 2016. Pengaruh CAR, LDR NPL dan terhadap ROA Pada Sektor Perbankan Di Bursa Efek Indonesia. E-Jurnal Vol. 5, Nomor. 5. ISSN : 2302-8912.

Zuhrotun. 2006. Keinformatifan Laba di Pasar Obligasi dan Saham : Uji Liquidation Option Hypothesis, Simposium Nasional Akuntansi IX Padang. 